\title{
The Effect of Dust Storm on the Microbial Quality of Ambient Air in Sanandaj: A City Located in the West of Iran
}

\author{
Heshmatollah Nourmoradi ${ }^{1}$, Kambiz Moradnejadi ${ }^{2}$, Fazel Mohammadi Moghadam ${ }^{3}$, Behdad Khosravi ${ }^{4}$, Lida \\ Hemati $^{1}$, Ramin Khoshniyat ${ }^{5}$ \& Farogh Kazembeigi ${ }^{1}$ \\ ${ }^{1}$ Department of Environmental Health Engineering, School of Health, Ilam University of Medical Sciences, Ilam, \\ Iran \\ ${ }^{2}$ Rural water and Wastewater Company. Ilam, Iran \\ ${ }^{3}$ Department of Environmental Health Engineering, School of Health, Shahrekord University of Medical \\ Sciences, Shahrekord, Iran \\ ${ }^{4}$ Department of Environmental Health Engineering, Ilam University of Medical Sciences, Ilam, Iran \\ ${ }^{5}$ Department of Environmental Health Engineering, School of Health, Kurdistan University of Medical Sciences, \\ Kurdistan, Iran \\ Correspondence: F. Kazembeigi, Department of Environmental Health Engineering, School of Health, Ilam \\ University of Medical Sciences, Pajouhesh Blvd, Banganjab, Ilam, Iran. Tel: 98-843-222-3077; Fax: \\ 98-843-222-3077. E-mail: faroogh_kazembigi@yahoo.com
}

Received: January 19, 2014 Accepted: February 27, 2015 Online Published: March 26, 2015

doi:10.5539/gjhs.v7n7p114 URL: http://dx.doi.org/10.5539/gjhs.v7n7p114

\begin{abstract}
Background and Aims: The presence of pathogenic microorganisms in the dust storm can cause diseases such as Asthma, Pneumonia, and respiratory infections. The aim of this study was to determine the relationship between air-borne particles with airborne microorganisms in normal and dusty days in Sanandaj, a city located in the west of Iran.

Materials and Methods: Air sampling was conducted during the normal and dusty days through Andersen single-stage impactor $(28.3 \mathrm{~L} / \mathrm{min})$ for $2.5 \mathrm{~min}$. Air particles concentration $\left(\mathrm{PM}_{10}\right)$ was measured daily and microbial sampling was also conducted on every six days and on the dusty days. Finally, the data was analyzed by SPSS-16 (ANOVA and paired T-tests).

Results: The concentration of airborne microorganisms (bacteria and fungi) was increased by an increase of the airborne particles. Particles concentration in May, June and July (twice per month) was more than of the standard value. The predominant species of bacteria and fungi during the occurrence of Dust storm was Bacillus spp. (56.2\% of total bacteria) and Mycosporium spp. (28.6\% of total fungi), respectively.

Discussion and Conclusion: The results showed that the number of airborne microorganisms (bacteria and fungi) increased during the dust storm. Therefore, the microorganisms in the dust storm can cause biological harmful effects on human health.
\end{abstract}

Keywords: air pollution, dust storm, bacteria, fungi

\section{Introduction}

The North wind is the major cause of dust storms to Iran country, especially the west of Iran. This wind, which is active every year from May to September, is formed in the north of Middle East and after passing through the mountains of Turkey country and northern Iraq country, moves forward until it reaches to Iran (Shahsavani et al., 2012). Major natural sources of dust storm are tropical, subtropical and desert areas (Amarloei, Jonidi Jafari, Asilian Mahabadi, Asadollahi, \& Nourmoradi, 2015). Among nine known regions in the world as the natural centers of dust storm, north of Africa is considered as the primary source which produces more than $50 \%$ of the airborne particles in the world. Tanaka and Chiba (2006) reported that the desert of Africa (Sahara desert) involves $58 \%$ of all the particles spreading on the Earth (Engelstaedter, Tegen, \& Washington, 2006). Dust storm produced in the west of China and certain parts of Mongolia has been considered as the second biggest source of dust storm in the world (Ohara, Clarke, \& Elatrash, 2006). The third source of dust storm causes by the Arabian 
Peninsula and its neighboring countries. This dust storm is the main cause of air pollutions in Iran (Goudie \& Middleton, 2001). In the past, Iran, Iraq and Saudi Arabia countries jointly conducted mulching these regions at certain times of every year. But, in recent years, due to the various problems, mulching these regions has not been happened. Therefore, this phenomenon has caused the dust storms in Iran, especially the west of Iran (Goudie \& Middleton, 2001). To the best of our knowledge, there were little studies conducted about Arabian dust storm. Draxler et al. (2001) reported that the average annual concentration of $\mathrm{PM}_{10}$ (particulate matter with aerodynamic diameter equal or less than 10 micrometer) in the air of Kuwait and Saudi Arabia countries, due to the Arabian dust storm, reached to $3000 \mu \mathrm{g} / \mathrm{m}^{3}$ (Draxler, Gillette, Kirkpatrick, \& Heller, 2001). $\mathrm{PM}_{10}$ can cause adverse health effects including asthma, pneumonia and respiratory tract infections in human (Sandstrom\& Forsberg, 2008). On the other hand, the microbial agents (bacteria and fungi) can travel long distances (5000 km) along with the airborne particles over the dust storms (Griffin, 2007; Prospero, Blades, Mathison, \& Naidu, 2005; Bovallius, Roffey\& Henningson, 1980). Griffin and Kellogg (2006) showed that the microorganisms such as Bacillus anthracis, Yersinia pestis, Mycobacterium tuberculosis, Legionella pneumophila and influenza virus in the dust storms can cause harmful effects on human health (Kellogg \& Griffin, 2006). In another study, Shahsavani et al. (2011) reported the dust storm increased the respiratory tract diseases and death rates in the dusty days of Ahwaz city, as one of the main cities of western Iran (Shahsavani et al., 2012). The aim of this study was to investigate the relation between air-borne particles with airborne microorganisms (bacterial and fungal organisms) in the normal and dusty days in Sanandaj city (Iran).

\section{Materials and Methods}

Sanandaj city is located in the western Iran $\left(35^{\circ} 18^{\prime} 52^{\prime \prime} \mathrm{N}, 46^{\circ} 59^{\prime} 32^{\prime \prime} \mathrm{E}\right)$. The population of the city is 374,000 people. The sampling was conducted in a single-point at city center of Sanandaj during the first 6 months of 2012 from April to September at the height of $3 \mathrm{~m}$ from the land surface. Grim sampler (Dustcheck 1.108 portable dust monitor) was used to measure 24-hour average $\mathrm{PM}_{10}$ concentration. Anderson single-stage sampler (SKC Inc.) at air rate of $28.3 \mathrm{~L} / \mathrm{min}$ for $2.5 \mathrm{~min}$ was used to determine bacteria and fungi in the air (Nourmoradi, Nikaeen, Amin, \& Hatamzadeh, 2011). PM $_{10}$ sampling was carried out daily but, the microbial sampling was taken every 7 days and also on the dusty days. Bacteria was cultured on heterotrophic plate count agar (HPA) at $37{ }^{\circ} \mathrm{C}$ for $48 \mathrm{hr}$. Sabouraud Dextrose agar (SDA) containing chloramphenicol antibiotic was also used to incubate fungal organisms at $25{ }^{\circ} \mathrm{C}$ for 3-5 days (Nourmoradi et al., 2011). Fungal organisms were distinguished microscopically (13). Completed culture media including Lowenstein-Jensen culture Medium for Mycobacterium spp., Mueller Hinton Agar for Pseudomonas spp. and blood agar for Bacillus spp. were also used to determine airborne bacterial species. The data was analyzed using SPSS-16 (ANOVA and paired T-tests). The p-value of 0.05 was considered as significant.

\section{Results}

Table 1 shows the $\mathrm{PM}_{10}$ concentration $\left(\mu \mathrm{g} / \mathrm{m}^{3}\right)$ and meteorological data of air during study. As seen, the maximum and minimum of the $\mathrm{PM}_{10}$ concentration were occurred at May-Jun $\left(191.7 \mu \mathrm{g} / \mathrm{m}^{3}\right)$ and at Mar-Apr $\left(73.3 \mu \mathrm{g} / \mathrm{m}^{3}\right)$, respectively. Fig 1 shows the airborne fungi, bacteria and $\mathrm{PM}_{10}$ concentration during the study. As seen, the concentration of bacteria was more than of fungi. Bacteria and fungi concentration was in the range of $1117-1927 \mathrm{cfu} / \mathrm{m}^{3}$ and $384-1679 \mathrm{cfu} / \mathrm{m}^{3}$, respectively.

Table 1. $\mathrm{PM}_{10}$ concentration $\left(\mu \mathrm{g} / \mathrm{m}^{3}\right)$ and meteorological conditions of air during the study

\begin{tabular}{|c|c|c|c|c|c|c|c|}
\hline \multirow{2}{*}{ Time } & \multicolumn{4}{|c|}{$\mathrm{PM}_{10}$ Concentration $\left(\mu \mathrm{g} / \mathrm{m}^{3}\right)$} & \multirow{2}{*}{$\begin{array}{l}\text { Mean wind } \\
\text { velocity }(\mathrm{m} / \mathrm{s})\end{array}$} & \multirow{2}{*}{$\begin{array}{l}\text { Maximum wind } \\
\text { velocity }(\mathrm{m} / \mathrm{s})\end{array}$} & \multirow{2}{*}{$\begin{array}{l}\text { Mean temperature } \\
\left({ }^{\circ} \mathrm{C}\right)\end{array}$} \\
\hline & Min & Max & Mean & St. Dev & & & \\
\hline Mar-Apr & 85.6 & 120.5 & 73.3 & 134.20 & 1.9 & 14 & 11.8 \\
\hline Apr-May & 68.3 & 264.0 & 156.4 & 372.18 & 2.2 & 11 & 15.1 \\
\hline May-Jun & 90.2 & 326.4 & 191.7 & 180.06 & 2.7 & 12 & 22.4 \\
\hline Jun-Jul & 80.6 & 125.3 & 115.4 & 143.35 & 2.5 & 9 & 27.0 \\
\hline Jul-Aug & 68.8 & 110.8 & 88.3 & 96.21 & 2.3 & 10 & 22.7 \\
\hline Aug-Sept & 63.0 & 90.9 & 75.0 & 65.97 & 1.8 & 9 & 23.5 \\
\hline
\end{tabular}




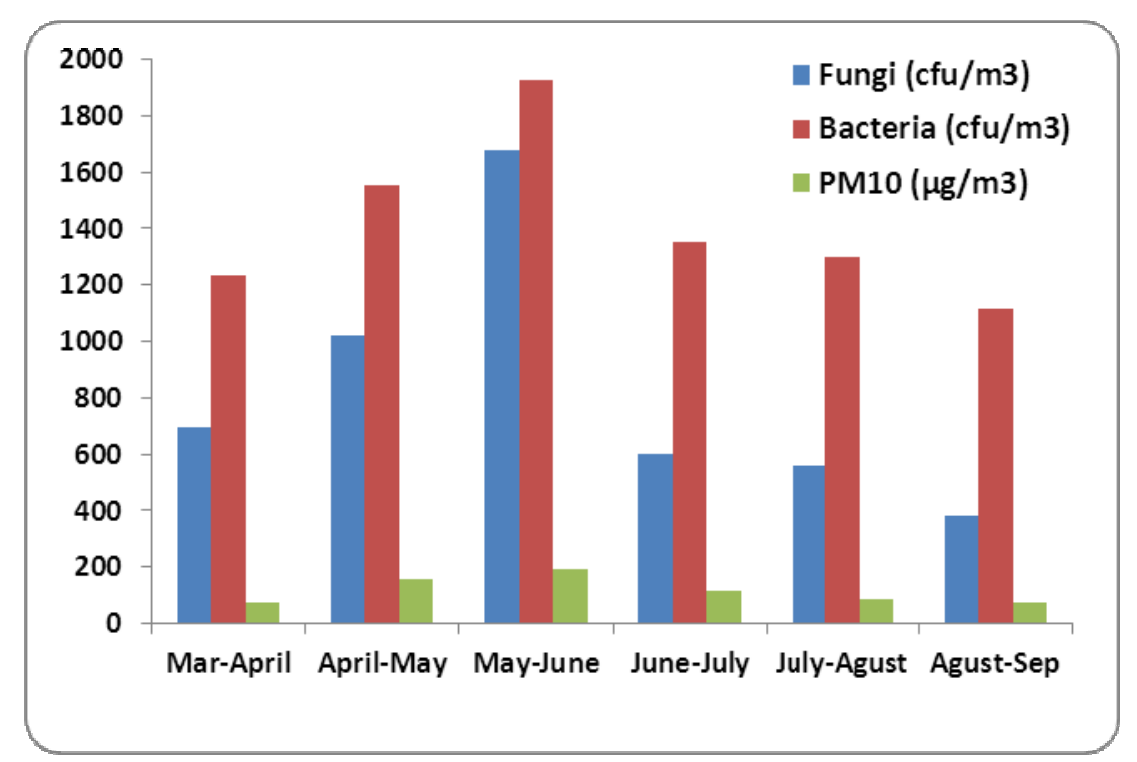

Figure 1. Airborne fungi, bacteria and $\mathrm{PM}_{10}$ concentration over the study

The relation between $\mathrm{PM}_{10}$ with bacterial and fungal organisms and the average wind velocity in normal and dusty conditions is presented in Table 2. Based on the results, Table 2, the relation between $\mathrm{PM}_{10}$ and the number of bacteria and fungi in the normal and dusty days was significant ( $\mathrm{p}$-value $<0.001$ ), except for bacteria concentration in the normal days $(p$-value $=0.961)$. Fig 2 and 3 show the predominant species of bacteria and fungi in the normal and dusty conditions, respectively. As can be seen, the predominantbacteria detected in the normal and dusty days were Bacillus spp. (56.2-66.6\% of total bacteria). The most common fungi species found in the normal and dusty days were Cladosporium spp. (31.3\% of total fungi) and Mycosporium spp. (28.6\% of total fungi), respectively.

Table 2. Relation between $\mathrm{PM}_{10}$ with microbial parameters and wind during the study

\begin{tabular}{lllll}
\hline Condition & Pollutant $\left(\mathbf{c f u} / \mathbf{m}^{3}\right)$ & Parameter & Mean & P-value \\
\hline Normal Days & $\mathrm{PM}_{10}$ & Bacteria $\left(\mathrm{cfu} / \mathrm{m}^{3}\right)$ & 1324 & 0.961 \\
& & Fungi $\left(\mathrm{cfu} / \mathrm{m}^{3}\right)$ & 592 & 0.000 \\
& & Wind $(\mathrm{m} / \mathrm{s})$ & 2.29 & 0.000 \\
Dusty Days & $\mathrm{PM}_{10}$ & Bacteria $\left(\mathrm{cfu} / \mathrm{m}^{3}\right)$ & 1995 & 0.000 \\
& & Fungi $\left(\mathrm{cfu} / \mathrm{m}^{3}\right)$ & 2268 & 0.000 \\
& & Wind $(\mathrm{m} / \mathrm{s})$ & 2.10 & 0.000 \\
\hline
\end{tabular}




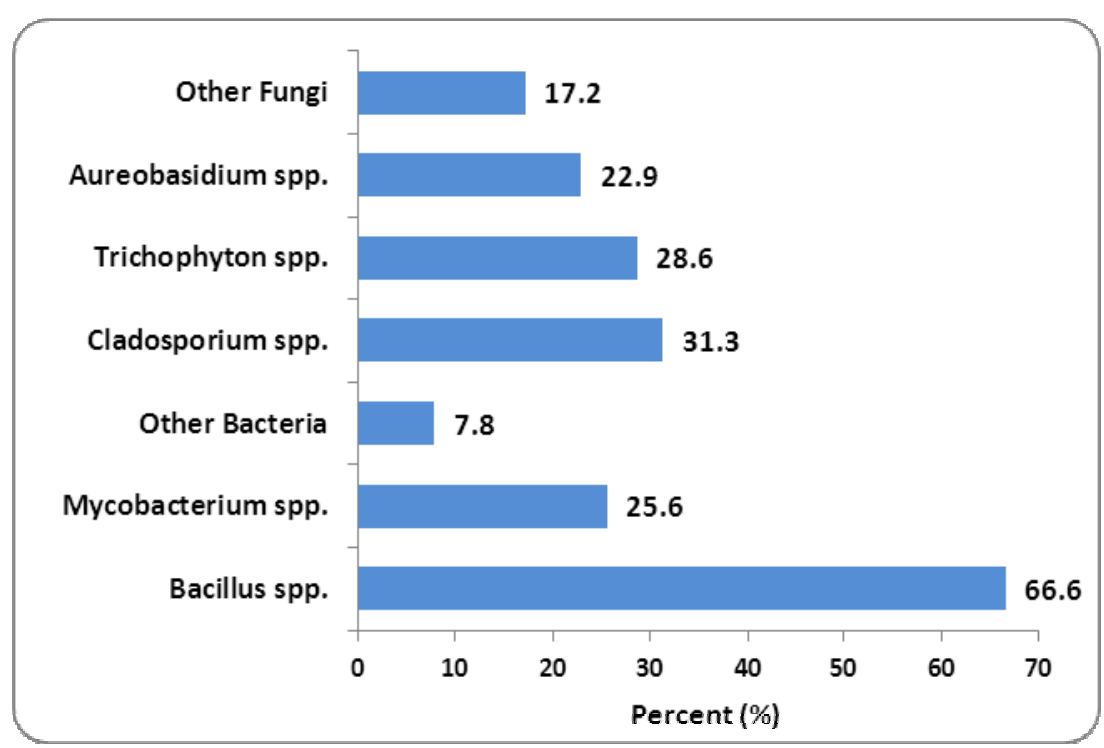

Figure 2. Airborne fungal and bacterial microorganisms in the normal days.

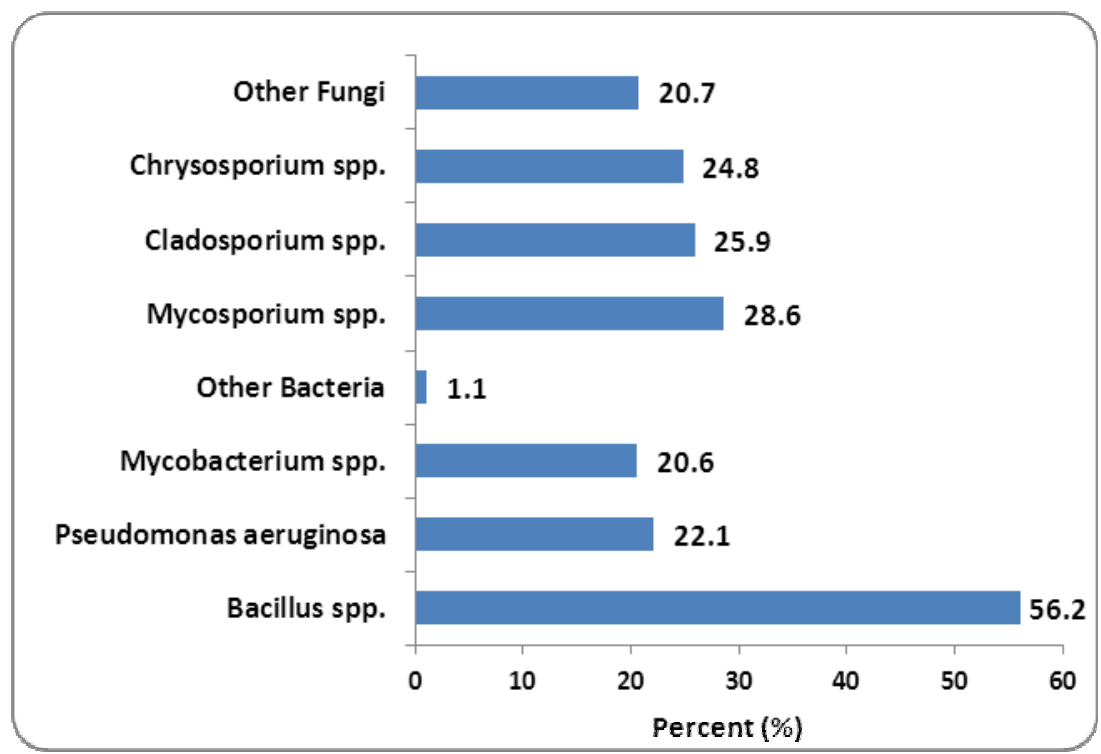

Figure 3. Airborne fungal and bacterial microorganisms in the dusty days

\section{Discussion and Conclusion}

This study showed that many microorganisms including bacteria and fungi were found along with Arabic dust storms. So, the number of microorganisms was increased as the airborne particles were raised. Particles concentration in May, June and July (twice per month) was more than of the standard value. In these months, as presented in Figure 1, the number of bacteria and fungi was increased. Weir et al. (2000) reported that pathogenic microorganisms can be transferredby dust storms over the worldwide (Weir-Brush, Garrison, Smith, \& Shinn, 2004). According to the study by Jeon et al. (2011) in South Korea, there was a significant positive correlations between $\mathrm{PM}_{10}$ and culturable bacterial population levels during the days affected by Asian dust events (ADE) (Jeon, H. J. Kim, Jung, J. H. Kim, M. Y. Kim, \& Y. P. Kim, 2011). The results of present study, Table 2, showed that the mean number of bacteria and fungi of air in dusty days was 1.5 times and 3.83 times of normal days, respectively. Griffin et al. (2003) showed that airborne microorganisms originated from Africa Sahara desert can be transmitted to Atlantic Ocean. They reported that the number of airborne microorganisms (bacteria and fungi) in dusty days was nearly 5 times of normal daysIn their study, Bacillus spp. and Cladosporium spp. were the most species of bacteria and fungi, respectively (Griffin, Kellogg, Garrison, Lisle, Borden, \& Shinn, 2003). The results of present study, Figures 2 and 3, also showed that Bacillus spp. (56.2-66.6\%) and Microsporum spp. 
(28.6\%) and Cladosporium spp. (31.3\%) were the predominant species of bacterial and fungal microorganisms detected over the normal and dusty days, respectively.Bacillus spp. due to their endospore and Microsporums spp. due to the existence of fat layer around the cell wall could tolerate the unfavorable environmental conditions such as sun's ultraviolet radiation and low temperature. Furthermore, because of the high concentration of dust particles, the penetration of sun's rays including ultraviolet over dust storm events is significantly reduced. This phenomenon can also increase the survival of the microorganisms in the air of dusty days (Rothschild \& Mancinelli, 2001). Maki et al. (2010) found that Bacillus spp., due to having endospore, was the main species of bacteria during dust storms in Japan (Maki, Susuki, Kobayashi, Kakikawa, Tobo, \& Yamada, 2010). Hara and Zhang (2011) reported that airborne bacterial concentrations in dusty days were $10^{6}$ to $1.6 \times 10^{7} \mathrm{CFU}$ per cubic meter, which were 1 to 2 times higher than of in normal days. They also presented that 16 to $40 \%$ of total bacteria in dust were viable. They concluded that the Asian dust is one of the most important processes to disperse airborne bacteria in the worldwide atmosphere (Hara \& Zhang, 2012). Fungal and bacterial organisms could be transmitted to far distance areas from the sources of dust production. Wind and turbulence of air are the important factors to spread of biological particles that cause to transfer fungi and bacteria from the original source to other areas (Lacey \& West, 2007). In our study, there was no significant difference between the averagewind velocityduringdusty daysandnormal days ( $p$-value $>0.05$ ). The present study showed that the mean velocity of wind was 1.8 to 2.7 meters per second. Kim and Chung (2010) reported that the wind velocity more than 8.0 meters per second results in the transfer of the dust particles from soil to the atmosphere (Kim \& Chung, 2010). Shahsavani et al. (2000) found that the deserts of Iraq is the main source of Arabic dust storm in ahwaz city (Iran). They reported that during 72 days of the dust pollution in ahwaz city (Iran) in 2010, a total morbidity and mortality was 8157 and 1131 individuals, respectively (Shahsavani et al., 2012). Meng and Lu (2007) reported that there was a statistically significant relationship between dust storms and mortality due to cardiovascular and respiratory disease, respiratory hospitalization, upper respiratory tract infection, pneumonia, hypertension. Therefore, because of the presence of microorganisms along with $\mathrm{PM}_{10}$, it is proposed to determine the potential effects of dust storm on the human and also ecological health in this region (Sanandaj city, Iran).

\section{Acknowledgments}

The authors express their thanks and appreciation to Mrs. Hossainzadeh (expert of Kurdistan Environmental Protection Agency, Iran) and Mrs. Bahmani (expert of Microbiology Laboratory of Sanandaj (Iran) Health Center).

\section{References}

Amarloei, A., Jonidi Jafari, A., Asilian Mahabadi, H., Asadollahi, K., \& Nourmoradi, H. (2015). Investigation on the Lung Function of General Population in Ilam, West of Iran, as a City Exposed to Dust Storm. Glob J Health Sci., 7(3), 298-308. http://dx.doi.org/10.5539/gjhs.v7n3p298

Bovallius, Å., Roffey, R., \& Henningson, E. (1980). Long-Range transmission of bacteria. Ann. N.Y. Acad. Sci., 353(1), 186-200. http://dx.doi.org/10.1111/j.1749-6632.1980.tb18922.x

Draxler, R. R., Gillette, D. A., Kirkpatrick, J. S., \& Heller, J. (2001). Estimating PM10air concentrations from dust storms in Iraq, Kuwait and Saudi Arabia. Atmos. Environ., 35(25), 4315-4330. http://dx.doi.org/10.1016/S1352-2310(01)00159-5

Engelstaedter, S., Tegen, I., \& Washington, R. (2006). North African dust emissions and transport. Earth Sci. Rev., 79(1), 73-100. http://dx.doi.org/10.1016/j.earscirev.2006.06.004

Goudie, A., \& Middleton, N. (2001). Saharan dust storms: nature and consequences. Earth Sci. Rev., 56(1), 179-204. http://dx.doi.org/10.1016/S0012-8252(01)00067-8

Griffin, D. W. (2007). Atmospheric movement of microorganisms in clouds of desert dust and implications for human health. Clin Microbiol Rev., 20(3), 459-77. http://dx.doi.org/10.1128/CMR.00039-06

Griffin, D. W., Kellogg, C. A., Garrison, V. H., Lisle, J. T., Borden, T. C., \& Shinn, E. A. (2003). Atmospheric microbiology in the northern Caribbean during African dust events. Aerobiologia, 19(3-4), 143-157. http://dx.doi.org/10.1023/B:AERO.0000006530.32845.8d

Hara, K., \& Zhang, D. (2012). Bacterial abundance and viability in long-range transported dust. Atmos. Environ., 47, 20-25. http://dx.doi.org/10.1016/j.atmosenv.2011.11.050

Jeon, E. M., Kim, H. J., Jung, K., Kim, J. H., Kim, M. Y., \& Kim, Y. P. (2011). Impact of Asian dust events on airborne bacterial community assessed by molecular analyses. Atmos. Environ., 45(25), 4313-4321. http://dx.doi.org/10.1016/j.atmosenv.2010.11.054 
Kellogg, C. A., \& Griffin, D. W. (2006). Aerobiology and the global transport of desert dust. Trends in ecology \& evolution, 21(11), 638-644. http://dx.doi.org/10.1016/j.tree.2006.07.004

Kim, H. S., \& Chung, Y. S. (2010). On the sandstorms and associated airborne dustfall episodes observed at Cheongwon in Korea in 2005. Air Qual Atmos Health., 3(2), 83-94. http://dx.doi.org/10.1007/s11869-009-0054-y

Lacey, M. E., \& West, J. S. (2007). The air spora: a manual for catching and identifying airborne biological particles. Springer.

Maki, T., Susuki, S., Kobayashi, F., Kakikawa, M., Tobo, Y., \& Yamada, M. (2010). Phylogenetic analysis of atmospheric halotolerant bacterial communities at high altitude in an Asian dust (KOSA) arrival region, Suzu City. Sci. Total Environ., 408(20), 4556-4562. http://dx.doi.org/10.1016/j.scitotenv.2010.04.002

Meng, Z., \& Lu, B. (2007). Dust events as a risk factor for daily hospitalization for respiratory and cardiovascular diseases in Minqin, China. Atmos. Environ., 41(33), 7048-7058. http://dx.doi.org/10.1016/j.atmosenv.2007.05.006

Nourmoradi, H., Nikaeen, M., Amin, M. M., \& Hatamzadeh, M. (2011). An Investigation on Bio-aerosol Concentrations in the Different Wards of Hospitals of Isfahan University of Medical Sciences. J Isfahan Med Sch., 29(149), 1028-1036. Retrieved from http://en.journals.sid.ir/ViewPaper.aspx?ID=221075

Nourmoradi, H., Nikaeen, M., Stensvold, C., \& Mirhendi, H. (2012). Ultraviolet irradiation: An effective inactivation method of Aspergillusspp. in water for the control of waterborne nosocomial Aspergillosis. Water Res., 46(18), 5935-5940. http://dx.doi.org/10.1016/j.watres.2012.08.015

Ohara, S. L., Clarke, M. L., \& Elatrash, M. S. (2006). Field measurements of desert dust deposition in Libya. Atmos. Environ., 40(21), 3881-3897. http://dx.doi.org/10.1016/j.atmosenv.2006.02.020

Prospero, J. M., Blades, E., Mathison, G., \& Naidu, R. (2005). Interhemispheric transport of viable fungi and bacteria from Africa to the Caribbean with soil dust. Aerobiologia. 21(1), 1-19. http://dx.doi.org/10.1007/s10453-004-5872-7

Rothschild, L. J., \& Mancinelli, R. L. (2001). Life in extreme environments. Nature. 409(6823), 1092-101. http://dx.doi.org/10.1038/35059215

Sandstrom, T., \& Forsberg, B. (2008). Desert dust: an unrecognized source of dangerous air pollution? Epidemiology, 19(6), 808-809. http://dx.doi.org/10.1097/EDE.0b013e31818809e0

Shahsavani, A., Naddafi, K., Jafarzade Haghighifard, N., Mesdaghinia, A., Yunesian, M., Nabizadeh, R., ... Goudarzib, G. (2012). The evaluation of PM10, PM2.5 and PM1concentrations during the Middle Eastern Dust (MED) events in Ahvaz, Iran, from april through september 2010. J. Arid. Environ., 77, 72-83. http://dx.doi.org/10.1016/j.jaridenv.2011.09.007

Weir-Brush, J., Garrison, V., Smith, G., \& Shinn, E. (2004). The relationship between gorgonian coral (Cnidaria: Gorgonacea) diseases and African dust storms. Aerobiologia, 20(2), 119-26. http://dx.doi.org/10.1023/B:AERO.0000032949.14023.3a

\section{Copyrights}

Copyright for this article is retained by the author(s), with first publication rights granted to the journal.

This is an open-access article distributed under the terms and conditions of the Creative Commons Attribution license (http://creativecommons.org/licenses/by/3.0/). 